\title{
EDITORIAL
}

\section{Novel Haemostatic Techniques In Military Medicine}

\author{
PF Mahoney, RJ Russell, MQ Russell, TJ Hodgetts
}

Uncontrolled external haemorrhage is predictably the most likely cause of avoidable pre-hospital death in combat and security operations. Enduring data from the Wound Data and Munition Effectiveness Team (WDMET) relating to 7989 US casualties of the Vietnam conflict indicates that bleeding from limb wounds accounts for over half the potentially preventable deaths in combat (others being airway obstruction, and haemorrhage that could be controlled surgically)(1). Champion et al have further estimated that $10 \%$ of all battlefield deaths are caused by haemorrhage from extremity wounds (2).

As death from exsanguination can occur in minutes it is necessary to place treatment capability far forward and to train and equip a range of medical and non-medical personnel. Every member of the Armed Services is taught the basic principles of haemorrhage control: put pressure on the wound, apply a field dressing and elevate the limb. But for some injuries this will not be enough (3). Additionally, while the aim is to evacuate casualties as quickly as possible from the battlefield, the reality on the ground is that evacuation is likely to be delayed by ongoing fighting or difficult terrain $(4,5)$.

The importance of identifying novel, simple and reliable field interventions to arrest traumatic haemorrhage in the combat environment has not been missed by industry. A comprehensive industry-wide review, led by Military Emergency Medicine, was undertaken in October 2004 and has led to a strategy for operational analysis and staged implementation of novel haemostatic techniques, with new products available to elements of deployed troops since April 2005.

The need for an improvement in the First Field Dressing (the military's general purpose wound dressing for combat casualties) was clear. Common practice had evolved to remove the non-distensible cotton ties and apply an elastic (crepe) bandage over the gauze wad in order to achieve adequate compression. The new dressing (The Emergency Care Bandage ${ }^{\mathrm{TM}}$ ) combines an absorbent pad with an elastic bandage, similar to the dressing widely used by US military and Israeli Defence Force personnel. An active choice was taken to exclude the option for incorporating a pressure bar, with emphasis placed on training the individual to apply digital pressure into the wound to further assist haemorrhage control.

Arterial tourniquets are part of established contemporary battlefield first aid training and practice. However, current civilian first aid guidelines for management of severe bleeding do not include tourniquets (6). This is not surprising as mortality from isolated extremity injury is rare in the civilian population (7) and hospitals are usually close to the point of wounding: the risks associated with tourniquets are, therefore, seen to outweigh the potential benefits. With the raised threat of military-type injuries from terrorist improvised explosive devices, civilian agencies may review this strategic choice.

Over 2500 US military deaths occurred in Vietnam from injuries confined to the extremities: this has been extrapolated to imply that $7 \%$ of combat deaths could be saved by using a tourniquet. Lakstein et al analysed the Israeli Defence Force experience of tourniquet use over a 4 year period (1997-2001). 91 of 550 patients (a combination of soldiers and civilians wounded in combat operations or terrorist attacks) had tourniquets applied. 17 casualties had more than one tourniquet applied. 125 patients died from their injuries, but none from uncontrolled limb haemorrhage. A tourniquet in this setting was a technique of failure, with personnel trained to use one only when pressure through a dressing was ineffective (8). The logical conclusion is that arterial tourniquets do save lives.

Coupland et al $(9,10)$ have suggested that use of a tourniquet can be classified as tactical (short term, applied at the point of injury to get rapid control of bleeding; may be self applied; reviewed when out of danger), a trial of tourniquet (when needed in addition to a pressure dressing and elevation, and reassessed at 2 hours after initial application) and a last resort (if bleeding continues after the tourniquet is released at the 2 hour point). The implication for the 'last resort' is that the limb will be lost unless rapid surgical intervention follows.

The Samway Anchor is the tourniquet currently in service. There are anecdotal internal reports that this device has failed in the desert setting due to the rubber perishing. Tourniquets available to the 
market were independently assessed by US and UK military academic institutions with overlapping conclusions (11). UK Defence Medical Services selected the Combat Application Tourniquet as the tourniquet that best combines the desirable features of robustness, simplicity, low weight $(<60 \mathrm{~g})$, compactness and a graded application of pressure.

Use of a tourniquet in first aid by nonmedical personnel has been taught as an improvised technique (12), but recent evidence demonstrates that a trained medic may take an average of 4.4 minutes to apply an effective improvised tourniquet in a model of femoral arterial bleeding (13). The Combat Application Tourniquet is designed to be rapidly applied in a fraction of this time; it may also be self-applied (as may a series of other commercial tourniquets) and is packaged in the 'one-handed' configuration to facilitate self-application. It is the intention that this equipment will be available at least as far forward as the emerging 'Army Team Medic' capability (one in four combat soldiers).

Some limb injuries are not amenable to the application of a tourniquet, including wounds to the groin, axilla and proximal extremity. This problem has been emphasised by Mabry et al (4) when describing US casualties sustained in Somalia. In their account one soldier died from a gun shot wound that lacerated his femoral artery and vein. The wound was too proximal for an effective tourniquet and haemorrhage could not be controlled by packing the wound with gauze: the casualty died 2.5 hours after injury.

Mabry et al (4) also describe the effectiveness of combat body armour (CBA) in reducing the number of fatal chest wounds, but point out how the face, neck, pelvis and groin remain vulnerable to severe injury. Similar observations have been made by Xydakis (14) and Hodgetts (15) with respect to the protective effect of CBA in operations in Iraq and Afghanistan.

Haemostatic dressings have been the subject of a continuing academic review on behalf of the Surgeon General both before and since Operation TELIC 1 (warfighting in Iraq, 2003) $(16,17)$. Quikclot ${ }^{\mathrm{TM}}$ (granular zeolite, derived from volcanic rock) is proven in swine models to be effective at controlling devastating haemorrhage from large vessels, but generates tissue temperatures up to $57^{\circ} \mathrm{C}$. This has raised the concern of associated tissue necrosis, although limited published data to date regarding changes in local tissue histology has not yet identified this to be a significant problem. HemCon ${ }^{\mathrm{TM}}$ (chitosan, derived from crushed shellfish) has performed comparably in animal models (excluding failure attributed to production techniques) and does not produce exothermia, but this alternative was unavailable to the UK market at the time of the industry-wide review. The initial choice of haemostatic dressing has, therefore, been pragmatic. The use of QuikClot ${ }^{\mathrm{TM}}$ by UK DMS is restricted to massive haemorrhage where conventional measures have failed and is controlled by clinical protocols.

Pre-deployment training and supply of the new products has been restricted to Medical Group personnel on Operation TELIC (Iraq) during the initial operational analysis phase. Both the user and the Trauma Team Leader have been required to complete an evaluation form, returned centrally via Permanent Joint Headquarters to the Royal Centre for Defence Medicine. In the forthcoming transition phase from analysis to 'in service' items it is anticipated there will be a degree of prioritisation dependent on operational need balanced with the cost of implementation.

The need for an emergent strategy is recognised, dependent upon the availability of alternative products to the UK market and their relative performance in clinical use. The application of different agents by individuals with a different level of competence, or in different clinical situations, is not excluded.

Clinicians' attitudes to the implementation of these novel techniques has been evaluated by means of a structured questionnaire administered before and after predeployment training and is reported later in this issue: the change in confidence of doctors, nurses and combat medical technicians to manage difficult wounds likely to cause severe haemorrhage (traumatic amputation; deep, ragged groin wound) was highly significant (18).

\section{References}

1. Bellamy RF. Combat trauma overview. In Zajtchuk R, Grande CM. eds. Textbook of Military Medicine Part IV: Surgical Combat Casualty Care: Anaesthesia and Perioperative Care of the Combat Casualty. Falls Church, VA: Office of the Surgeon General, US Army:1995:1-42.

2. Champion HR, Bellamy RF, Roberts $P$, Leppaniemi A. A profile of combat injury. J Trauma 2003;54:S13-S19.

3. Cloonan CC. Treating traumatic bleeding in a combat setting. Military Medicine Dec 2004169 (12 Suppl):8-10, 4 .

4. Mabry RL, Holcomb JB, Baker AM, Cloonan CC, Uhorchak JM, Perkins DE, Canfield AJ, Hagmann JH. United States Army Rangers in Somalia: an analysis of Combat Casualties on an Urban Battlefield. J Trauma 2000;49:515-529.

5. Bilski TR, Baker BC, Grove JR, Hinks RP, Harrison MJ, Sabra JP, Temerlin SM, Rhee P. Battlefield casualties treated at Camp Rhino, Afghanistan: lessons learned. J Trauma2003;54 (5):814-21.

6. British Red Cross. Practical First Aid. Dorling Kindersley, London 2003.

7. Dorlac WC, Debakey ME, Holcomb JB, Fagan SP, Kwong KL, Dorlac GR, Schreiber MA, Persse DE, Moore FA, Mattox KL. Mortality from isolated civilian penetrating extremity injury. I Trauma 2005;59 (1):217-22.

8. Lakstein DL, Blumenfeld A, Sokolov T, Lin G, Bssorai R, Lynn M, Ben-Abraham R. Tourniquets for hemorrhage control on the battlefield: A 4 year 
accumulated experience. J Trauma 2003;54:S221S225.

9. Coupland RM, Molde A, Navein J. Care in the field for victims of weapons of war. ICRC 2001.

10. Navein J, Coupland R, Dunn R. The tourniquet controversy. J Trauma 2003;54:S219-S220.

11. Wenke JC et al. Physiological Evaluation of the OneHanded Tourniquet. Military Medicine, In Press.

12. Battlefield Casualty Drills, 2004, Army Code 71638.

13. Mabry RL. Use of a hemorrhage simulator to train military medics. Military Medicine, In Press.

14. Xydakis MS, Casler JD. Analysis of battlefield head and neck injuries in Iraq and Afghanistan. Otolaryngology, Head and Neck Surgery. Vol 131, Issue 2, August 2004, P72 (Conference proceedings).
15. Hodgetts TJ, Mahoney PF. Operational Surgical Services Review. Academic Department of Military Emergency Medicine, Royal Centre for Defence Medicine. January 2005.

16. Garner JP. Review of novel haemostatic agents for field use. Dstl/CBS/BTP/TG2/TECH/3 13 Nov 02.

17. Parry CA, Green M. The evidence for use of Quikclot $^{\mathrm{TM}}, H_{\text {emcon }}^{\mathrm{TM}}$ and the Rapid Deployment Hemostat Bandage ${ }^{\mathrm{TM}}$ in haemorrhage control. Dstl report $26 / 11 / 04$.

18. Hodgetts TJ, Russell RJ, Mahone PF, Russell MQ, Kenward G (2005). Evaluation of clinician attitudes to the implementation of novel haemostatic techniques. J Roy Army Med Corps 2005;151:175-177. 